\title{
Forum
}

\section{Reflections on the Tsunami}

\author{
Imam Zaid Shakir
}

\author{
Wa'1 `Asr Innal Insana lafi Khusr...'
}

By the testimony of time, surely humankind is in a state of loss...

The exegetes mention that the testimony of time, mentioned in this verse, refers to the testimony of each era's extraordinary events, events that indicate the incomparable power of God. ${ }^{2}$ In our time we have seen many such events. The recent tsunami, which devastated regions in and around the Indian Ocean, is only the latest. Only God could have ushered the awesome power unleashed by the earthquake that moved the island of Sumatra 100 feet, yet left it intact. Only God could have ushered the awesome power to send a wave of water, whose depth reached from the surface of the water to the ocean floor, hundreds of miles across the sea at speeds exceeding five hundred miles an hour. Only God could devise an "early warning system" which told myriad species of animals to flee to the safety of high ground. Only God.

Yet many, even some professing faith in Islam, having seen such an awesome display of God's power, question His wisdom. Why must our faith be constantly tested? Why did so many unsuspecting people have to perish? Why were children swept from their mothers' arms? Why such widespread and apparently wanton destruction? Why, once again, are Muslims the majority of those suffering from such calamities? Why?

Imam Zaid Shakir, one of the most respected and influential Muslim scholars in the West, accepted Islam in 1977 while serving in the United States Air Force. He has a B.A. in international relations (American University), an M.A. in political science (Rutgers University), and is a graduate of Syria's prestigious Abu Noor University, where he immersed himself in an intense study of Arabic, Islamic law, Qur'anic studies, and Islamic spirituality. Now a scholar-in-residence and lecturer at Zaytuna Institute, he teaches Arabic, Islamic law, history, and Islamic spirituality. This article orginally appeared on www.zaytuna.org. 
In many instances, for Muslims, such questions may arise from ignorance of basic religious teachings and an insufficient knowledge of Islamic eschatology. Let us endeavor to answer some of the above questions. Perhaps, by so doing we can see the wisdom of God as it manifests itself in events such as the recent tsunami.

This world, as God repeatedly informs us in the Qur'an, is the abode of trials and tribulations. God says: "He who has created death and life in order to test which of you is best in deed. He is overwhelmingly mighty, oft-forgiving." ${ }^{3} \mathrm{He}$ also says: "We will surely test you with a measure of fear and hunger, and loss of wealth, lives, and the fruit [of your fields and labor]. Give glad tidings to those who patiently persevere." ${ }^{4}$ Similarly: "Do people think that they will be left alone merely saying: 'We believe!' and not be tested?"' All of these verses emphasize that this world is an abode of tests. The object of life is not to avoid or deny its tests and trials, [but] rather to successfully pass them.

Another verse forthrightly presents a fact alluded to in the above citations. Namely, the tests in this world will involve what we refer to as good, and what we refer to as evil. God says in that regard: "Every soul will experience death, and we will test you with evil and good, as a trial; and unto us you will return." ${ }^{\prime 6}$ This verse makes it clear that God has never promised us a rose garden in this worldly life. Muslims were never promised that we would win every battle. ' We were never promised that our "ummah" would march triumphantly through history, in Hegelian or Darwinian fashion, leaving inferior systems of belief and social organization strewn in our wake. And we were certainly never promised that we, contrary to the view of some Islamic thinkers, especially those influenced by positivist philosophy, ${ }^{8}$ would be able through science to conquer the forces of nature which have always hung menacingly over the head of humanity, threatening to forever trap us in the "misery of the human condition."

The great sage Ibn 'Ata Allah as-Sakandari beautifully captured the reality of this world, and what our expectations in it should be, when he said:

Do not find the occurrence of tribulations strange as long as you are in this worldly abode, for it [the world] has only manifested its deserved description, its intrinsic characteristic.?

Living in this world will inevitably bring us tests. Those tests are subtle and open; they occur in great and small things. Through these tests, God shows which of us truly believe and which of us are empty claimants. ${ }^{10}$ Many think that tests from God are always signs of His wrath. As Muslims, 
we believe that the trials afflicting us can be signs of His love. God's Messenger informed us:

The magnitude of otherworldly reward is proportionate to the magnitude of worldly tribulation. When God loves a people, He tries them. Whoever is content [with God's decree], will have divine pleasure. Whoever is displeased [with God's decree] will have divine wrath. ${ }^{11}$

As the Prophets are the most beloved of humanity with God, it follows that their tribulations should be greater than those of ordinary folks. This is indeed the case. The Prophet, peace and blessing of God upon him, was asked: "Which group of people are most severely tested?" He replied: "The Prophets, then people according to their spiritual rank. People are tested according to their faith." 12 'Aisha, God be pleased with her, reported: "I never saw anyone more stricken with pain than the Messenger of God, peace and blessings of God upon him."13

Just as God has informed us that tests and tribulations are the nature of this world, his Messenger, peace and blessings of God upon him, has informed us that those tests will include earthquakes and other natural disasters. He said, for example:

The hour will not come until knowledge is taken away, earthquakes become numerous, time passes quickly, tribulations appear, chaos reigns - that is to say widespread killing; [it will not occur] until wealth becomes abundant among you, to a point where it is superfluous. ${ }^{14}$

This particular tradition aptly describes our times. That being the case, we should view the oftentimes unsettling events transpiring contemporarily as a fulfillment of what our Prophet, peace and blessings of God upon him, has foretold. The occurrence of these events should only strengthen our faith, deepen our conviction to avoid participating in the strife that he predicted, and inspire us to work to alleviate the suffering of those immediately affected.

Human suffering is real. However, human perseverance and human dignity are just as real. They allow us to nobly endure the trials of this world. As Muslims, we are assisted toward this end by our knowledge that any suffering we experience in this world expiates our sins. Our Prophet, peace and blessings of God upon him, said: "There is no calamity that afflicts the Muslim except that for that God expiates his sins, even [something as slight] as a thorn that pricks him." ${ }^{15} \mathrm{He}$ similarly declared: "Nothing afflicts the Muslim, neither fatigue, pain, anxiety, sadness, injury, 
nor grief; even the pricking of a thorn except that for that God expiates some of his sins." 16

These narrations call our attention to the fact that the believer's brief stint in this world is a preparation for eternal life. Our understanding of suffering, justice, the trials of this world, and many other issues integral to any meaningful assessment of the human condition are incomplete and inevitably misleading when they are divorced from consideration of the next, eternal life. If one's view of human life is limited to this world, one might easily be led to view the suffering and travails of this world as manifestations of injustice or cruelty. However, when one relates those hardships to the life hereafter, one must confront the question: "How bad can any suffering in this world be if it opens the door to unimaginable, eternal good in the life hereafter?"

In conclusion, those who drowned in the tsunami are martyrs. Those who were crushed by demolished structures are martyrs. Those who will die of dysentery or cholera will be martyrs. They have all gone on or will go on to the good that God had prepared for them. Our Prophet mentioned in that regard:

The martyrs are five ${ }^{17}$ : One who dies during the plague; one who dies of dysentery; one who dies by drowning; one who dies in a demolished structure; and one who dies struggling in the way of God. ${ }^{18}$

Paradise will be theirs. Their cases are closed.

As for us, what will be our case? Will we humble ourselves before the awesome power of God, or will we continue to display our destructive hubris? Will we continue to take the blessings of food, clean drinking water, and shelter for granted, or will we fall unto our knees, raising our hands to the sky, our eyes flowing over with tears, thanking God for these blessings from the depth of our hearts? Will we forget about the suffering victims of the tsunami as soon as the gatekeepers decide that other stories are more newsworthy and the images disappear from our televisions, or will we continue our relief and fundraising efforts? And perhaps most importantly, will we watch scores of people bury their dead, and continue to neglect preparation for our own inevitable demise?

\section{Endnotes}

1. Al-Qur'an 103:1-2.

2. See, for example, Muhammad 'Ali As-Sabuni, Safwa at-Tafasir (Beirut: Dar al-Qur'an al-Karim, 1406/1981), 3:600. He says: "He (God), be He exalted, 
swears by the 'Asr, which is the time. It calls attention to what it contains of the age(s) witnessed by humanity, and what it contains of various incredible events, and signs indicating the power of God."

3. Al-Qur'an 67:2.

4. Al-Qur'an 2:155.

5. Al-Qur'an 29:2.

6. Al-Qur'an 21:35.

7. One could reflect on the message of Al-Qur'an 3:140, to ascertain the veracity of this statement. In this verse God mentions: "These varying fortunes victory, defeat; strength, weakness; influence, impotence we alternate between people. This is in order that God shows who truly believes, and that He takes from your ranks martyrs. And God loves not oppressors."

8. The influence of Comtean positivism was especially strong in 19th century Egypt. Its influence on Muhammad `Abduh is undeniable. `Abduh wedded that positivism to his effort to create what he viewed as a viable Islamic worldview, along with a viable political and social morality. 'Abduh then influenced a generation of Islamist thinkers, most importantly Rashid Rida. Through them, positivist thinking became one of the distinguishing features of the 20th century Islamic movement. For an indication of Comte's influence on 'Abduh, see Albert Hourani, Arabic Thought in the Liberal Age 1798-1939 (Cambridge: Cambridge University Press, 2003), 138-40.

9. Ibn 'Ata Allah as-Sakandari, Al-Hikam wa'l Munajata al-Ilahiyya (Damascus: al-Maktaba al-'Arabiyya, n.d.), 19.

10. Al-Qur'an 29:3. In this verse, God says, concerning the tests of this world: "In order that God will show which of you are truthful, and which of you are liars."

11. At-Tirmidhi, \#2396.

12. At-Tirmidhi, $\# 2398$.

13. At-Tirmidhi, \#2397. The crushing pain which afflicted the Messenger of God, peace and blessings of God be upon him, occurred during his final illness.

14. Al-Bukhari, \#1036.

15. Al-Bukhari, $\# 5640$.

16. Al-Bukhari, \#5641.

17. There are other categories of martyrs. Five are mentioned in this tradition. However, the number is not meant to be definitive. One may note that even this tradition has been mentioned by Imam al-Bukhari, in the "Chapter of Tribulations" (Kitab al-Fitan), in a section entitled "Martyrdom Includes Seven Groups Besides Those Killed in Battle." Others mentioned by Ibn Hajar in his discussion include: A woman who dies during childbirth; one dying of tuberculosis; one killed defending his wealth, his religion, or his family; one who dies while guarding the frontiers of the Islamic realm; and other categories. See Ibn Hajar al-'Asqalani, Fath al-Bari: Sharh Sahih alBukhari (Damascus: Dar al-Fayha', 1997/1418), 6:53-54.

18. Al-Bukhari \#653; and \#2829. 